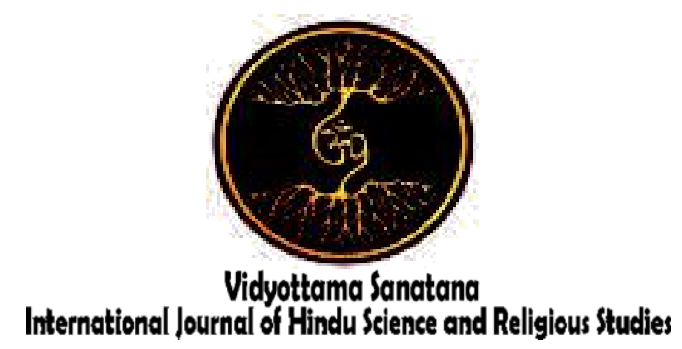

Vol. 2 No. 1 May 2018

\title{
Death as a way of 'freedom' for Spirit to Eternity (Hindu Kaharingan Theological Perspective)
}

\author{
By: \\ Tiwi Etika \\ Institut Agama Hindu Negeri Tampung Penyang Palangkaraya \\ E-mail: tiwietika@stahn.ac.id
}

Received: November 20, 2017

Accepted: May 5, 2018

Published: May 31, 2018

\begin{abstract}
Discussing about death has always been the most interesting issue of every religion in the world. Human fears death and do not want to die. For some people, death becomes so familiar that fear becomes daring, in some sense, they are ready to lose everything, or at least, no longer expects anything, as heroes did on the battlefield. Brhad-aranyaka Upanisad IV.3.36 has mentioned that: when this body starts to frail, whether it frails through old age or disease, just as a mango or a fig or a fruit of the Peplum tree releases itself from its bond (gets detached from its stalk), even so this person frees himself from these limbs and returns again as he came to the place from which he started back to a new life. Data was collected using desk study and analyzed using Hindu studies. The finding of this research that man as a descendant of Raja Bunu who inhabits this world will someday return to Ranying Hatalla through death. Life is temporary, as an exodus that someday will return to where we came from. Just as policemen, magistrates, chariot-drivers, leaders of the village gathered round for king's departure, or as breaths gather round at the end, when a person starts breathing difficultly or when he is about to die, that is when death is a way of "freedom' to the eternity.
\end{abstract}

Keywords: Death, Freedom, Spirit, Eternity and Hindu Kaharingan

\section{Introduction}

It is a human nature to receive life with joy and excitement, as the world gives abundant blessings to human kind. Therefore, in their mind the world is full of beauty, comfort and pleasure. Human also feel that 
there should be an accord relationship between human kind, nature, other living creatures, love, devotion and trust with God as the creator, helper and best hope in joy and grief. Because of all of those qualities, in relationship with other creature, humans are gifted with sensitivity to feel happiness and emotions, smiles and laughter. Like a newly happy weds couple that just finishes their wedding ceremony, greeting guests with smile and expressing their gratitude for attending their wedding reception. Or in their relationship with nature and other creature, humans are gifted with sensitivity to enjoy the beauty of nature, love and blessing from other creatures. For example how beautiful the sound of frogs when rain comes to wet the earth and how morning dewdrop dripping down leaves on sunrise. Or how much fun it is to celebrate New Year's Eve with friends, relatives and spouse. Regarding to the relationship with God, human is also gifted with faith and hope for salvation, prosperity, and endless happiness in life and ever after life. It is very difficult for human to leave beauty and worldly pleasure when they are faced with the certainty of death, where all the worldly pleasure will not be found or felt, prayers of hope can no longer be uttered, the sound of birds and frogs cannot be heard, the warmth of embrace from friends and loved ones can no longer be felt, all of them gone in a condition we call death (Hericus Darmada, 2000: 2).

The binding worldly pleasure has made human become fearful and even feel taboo to think and even speak about death. Death is often understood by general society as the absence of soul in human's biological form. This condition is inevitable, because all living creature will die eventually, whether by natural cause such as sickness or other cause such as war, felony, nature disaster, transportation accident and others. The discussion of death can cause psychological problem by someone who is not ready mentally to end worldly life and become addicted with life. Regarding to this death, the book of Brhadaranyaka Upanisad said about death as following:

Like a moving cart full of load groaning, so as the cart of human's soul lives, moves, and groans when he stops breathing. As a mango or a fruit fall from a holy fig tree, off from its branches, as human's soul released from his body and returns to life, wherever it comes from. As when a king arrives, nobles and courtiers, coachmen and head village prepares banquet and place to stay, as a guard say: "The King is coming and will soon be arrived", as in the same manner all of the living forces waiting and say "The Soul is coming, and soon be arrived," and as when the King departing, all the nobles and courtiers, coachmen and head of village gathered surround him, as when all living forces gather surrounds the soul when a human take his final breath (Juan Masearo \& Swami Harhananda, 2012: 143).

Book of Bhagavadgìtā II.22 stated: vāsāmsi jūrnani yathā vihāya navāni gṛhnait naro 'parāni, tathā sarirani vihāya jīrnany ānyani samyati navāni deh̄i. Translation:

As a person leaves his old used garments and replace them with new ones, as the same with jivatman leaves his old body and enters to a new body (G. Pudja, 2005: 45). 
When death is connected with life in religious aspects, especially in Hindu, death is not just the gate to valley of grave or a way to a place of burial where one waits for his final journey and part with his body and soul. More than that, death is a cycle or process to eternal realm, where human come from. Therefore if death will be experienced by every living creature then the most fundamental question in every human's mind is 'What is death and why does every creature must experience it? Is death a pleasant condition or is it a horrific condition? And what will happen when a person meets death? This paper is hoped to give answers to all of those questions from the perspective of Hindu Kaharingan Theology.

Hindu Kaharingan is an integral part of Hindu, the majority religion of subs native Dayak in Kalimantan Island (Borneo), Indonesia. In year 1980 the Kaharingan religion is integrated with Hindu to receive recognition from Indonesian government, which then it is called Hindu Kaharingan. The Hindu Kaharingan religion spreads across Kalimantan- Indonesia, approximately more than 1.500.000. However according to demography records there are less than that. This is because most of Hindu Kaharingan lives in district remote islands, which are not recorded, and some has converted to other religion.

The data used in this paper is obtained with descriptive qualitative approach of Hindu Studies and analyzed with perception interpersonal theory by Stephen P. Robbins and purpose theory by Ausubel. The purpose of this article is to understand and finding the meaning of death for human from the perspective of Hindu Kaharingan Theology as a reminder that death is inevitable and will be experienced by every human being. Therefore human mentally can understand and accept death sincerely as to free soul from body to the realm of eternity, A realm without taint, suffering, samsara and joy forever.

\section{Result and Discussion}

Many scientists or medical doctors would explain that a person who dies is a person whose heart has stopped, when his blood pressure decreases and can't be measured again or when he stops breathing for a very long time. With the advance of technology, death can be determined more accurately by using a device that can measure the amount of electric current on brain (electron- encephalograph apparatus), which can detect any brain activity. The science of medicine believes that all human activity centralized by brain as the controller. Therefore when a person is determinesed to be dead then his brain would also stop functioning. That is the definition of death according to medical science. Whether the definition is true or false regarding to the time of death, at the end according to science death is understood as a condition when a person can't be alive anymore (Henricus Darmada, 2000: 9).

In Muhammad Damm's book called: "Kematian-Sebuah Risalah Tentang Eksistensi dan Ketiadaan" (Death-Report on Its Existence and Absences), he explained in secular perspective, without religion perspective (Person who does not have religion also faces death when the cause is found). Muhammad Damm sees death from other perspective, which is not commonly sought out by most people in general. He took the definition of death to philosophical understanding called post phenomenology. The word post phenomenology is not a common word by most people because logic is place first to make conclusion from a 
thought, whereas religion does not involve that understanding at all. Because of that, death according to Muhammad Damm can be understood with several understandings. First, death is as the completion of a process of dying. We call this as denouement death (death as solution). Secondly, death can be understood as the beginning from a process of dying; a point where there is no way to reverse condition (point of no return) or can be called threshold death (death as the limit). Third, death is an inability of body organism to integrate and function, which called total death. Despites of those understandings, it is possible to say that the principle of Atheism perceived death is a natural process or law of nature. Meanwhile, people with religious believe would say that death is a pathway for human to meet with their creator and is the separation of body and soul. According to an Ancient believe, man tends to believe that enemy or evil spirit causes death. There is no such thing as natural cause. Death can be perceived as something natural, in sense that it is certain and even compulsory to. However Ancient believes say that it as punishment from God or a misfortune that caused by something unnatural (Muhammad Damm, 2011: 61).

Death is certain, which makes it closer than any other possibility in life. According to Gede Prama, death is not the opposite of life. Death is parallel with life. Only by having good understanding of death human can live better in this lifetime and died peacefully when the time comes. Therefore we should appreciate death as we appreciate birth as something that we should be grateful and celebrated with joy and wisdom. However this is very difficult for a person who has not have enlightenment about death. Because nobody can be exactly sure what happens when a person dies. Except things that are known from faith of certain believe (Komaruddin Hidayat, 2008: 13).

\subsection{Personal conflict that is faced by human's spirit after its physical being experience death}

When a person is still on material realm, he would be covered in filth and dirt of worldly matter. Even when he has been through evolution of life, his material filth would not be clean; therefore worldly temptation would still be upon him, this indicates that his spirit is still not cleansed. After a human dies, this spirit automatically enters the spirit realm. I would describe the spirit realm is like a pool of water. The spirit that goes there fit according to its weight. When the spirit's weight is too heavy, it would sink to the bottom of the pool, which is called hell, if it weighs lighter from worldly temptation it would float on the surface of the pool, which is called heaven. In reality, spirit realm is a realm of light; the realm of light energy, every creature is in a form of light. There is no male or female, beautiful woman only exist on earth. Creatures in spirit realm also experience evolution to enter Purusa realm, where every personality disappears and unites to universal realization.

\subsection{The difference between human soul and spirit}

The word "spirit" refers to non-material aspects from human. Human has spirit, but human is not a spirit. However according to holy book of Bible, only believers, those who have Holy Spirit inside them can be called "living creature in spirit" (1 Corinthians 2:11, Hebrew 4:12; James 2:26). A non-believer is "spiritually dead" (Ephesians 2:1-5, Colossians 2: 13). In book of Paul, "Spirit" is 
very important to believer's spiritual life (1 Corinthians 2:14; 3:1; 15:45; Ephesians 1:13; 5:19; Colossians 1:9; 3:16). Spirit is an element inside human that can make it possible to connect with God. Every time the word "spirit" is used, it is referring to the nonmaterial part of human, including his soul. The word "soul" is only not referring to the non-material part of human but it also refers to the material part of human. It is different to just having a spirit inside but basically human is the soul. The meaning of "soul" is "living". However, in the holy book of Bible, the word does not only mean "living" it also means other things. One of them is the willing to sin (Luke 12:26). Fundamentally, human is evil and his soul is tainted where the end of his life is physical death. One of it is the will to sin (Luke 12:26). "Soul" and "spirit" is the center of spiritual and emotional experience (Job 30:25; Psalm 43:5; Jeremiah 13:17). Every time the word "spirit" is used, it refers to a person whether he is alive or dead. "Soul" and "Spirit" are both used in a believer's spiritual life. The difference lays on the reference of "soul" is from human's perception horizontally towards the world. Whereas, 'spirit' is human's perception vertically between human and God. It is important to understand that both references are referring to the non-material part of human, however only "spirit" that refers to a life between human and God whereas "soul" refers the life of human on earth whether it is the material and non-material part of human (Tiwi Etika, 2017: 146).

\subsection{The Existence of Spirit in the Book of Panaturan}

Inanjuri ganan tandak, balua bulau pantar tatah bahanjung rabia saduringuntum. Bahi-bahing panganak andau balua parung hai malabehu benteng, siru datuh marantau ruang ije gantung pahalendang tinggi pahalingei, ruwan parung hai Babahingan panyandai bulan nehus siru sari pangku palus nyalumbu ambun tilap telu puluh malangkawet enun lime balas hatalamping. Palus tapuk Tasik Kapanjungan Manjung halawu tumbang lawang langit, kangkarungut ganan tandak namuei nuking uju lawang langit uju najung ingang kalau. Eleh tapuk Tasik Malambung Bulau harende laut bapantan hintan, palus murik Batang Danum Mendeng Ngatimbung Langit, nanturung pahalendang Balai Bulau Napatah Hintan, Balai Hintan Napatah Bulau sali padadusan Ranying Hatalla Langit Tuhan Tambing Kabanteran Bulan Raja Tuntung Matan Andau Jatha Balawang Bulau Kanaruhan Bapager Hintan, ije hai kuasae belum datuh japa-jimat hamaring...

Translation:

(I call upon Bahing Ganan Tandak Rabia Lambatan Karunyangku (voice of my spirit) to come forward from its origin which placed by Ranying Hatalla to my throat, through my white teeth and my tongue which diligently prays, and come out from the door upon my house raise to Heaven, traverse to thirty layered dew, breaking through fifteen stacks of room to Panyungan Manjung which moves mighty eagle on Langit to Tasik Malambung Bulau, Laut Bapantan Intan, it can be seen the radiance of holy light of Balai Bulau Napatah Hintan, Balai Intan Napatah Bulau. Throne of Ranying Hatalla Langit Tuhan Tambing Kabanteran 
Bulau Jatha Balawang Bulau Kanaruhan Bapagar Hintan...).

... Palus buli ganan tandak, buli batambang salumpuk entang, mules lepah labatan ganan kandayung mulang tantakep tanterus tuyang. Buli hayak ganan tandak, buli bulau pantar tatah, mules lepah ganan kandayung nyuruk rabia sadurin guntum, rowan junjun helu.

Kuruk hambaruan ikei buli nyelem bangkusan timpung, mangat hariten halawu bentang, uka barintih nduan hila upun tundue, buli hayak panyalembang untek, panarang atei, parentas rawei, paharus jalan, parajang hukum, buli hayak kayun penyang karuhei tatau sandik paturung sangkalemu raja.

Translation:

... The voice of my holy spirit, return to where you come from, return through my teeth and enter to my tongue, your origin throne, as the same for the blessing and grace of Ranying Hatalla inside us, therefore we prospers, live long and given good health (Opening prayer of Basarah).

Observing from the opening prayer of Basarah above, states that a voice of a person's spirit is praying to communicate with Ranying Hatalla to say his wishes. Based on that understanding, it can be simplified that a person has more than one spirit. However if deeper analysis is done there is only one spirit found in each person. This can be seen from an event when a person is praying and transcending his spirit voice like above but forget to chant his prayers to return the spirit voice to the person's throat, when this happens that person may experience death. Logically, if there were more than one spirit within human, when the voice spirit does not return, the person would only lose his voice. However, in several cases especially when it is done as a special ritual, when the spirit voice is used to communicate with Ranying Hatalla cannot return to the person's body, then that person might lose his life forever. Therefore the spirit voice that is mentioned and uttered in the opening prayer is from the spirit (ātman).

In the Book of Panaturan Chapter 20 verse 11 states that spirit called Hambaruan is a fragment of light from Ranying Hatalla itself. Therefore, it can be understood if spirit (Hambaruan) can communicate and if one day experience death, it will return to Ranying Hatalla, as it is part of itself. The analogy would be like a metal of rod when touches or weld will come together as one. It would not mend with other kind of element such as wood or others. Same goes with the existence of Ranying Hatalla and Hambaruan (spirit) both can come again together as one because they come from the same element. This strengthens the logical believe of Hindu Kaharingan, when human experience death, then the spirit will go through death process and will unite again with Ranying Hatalla. This is very different to other theological death believe of Jews, Christianity and Islam. However, it is very similar and even the same with Hindu theology that states when human experience death, then atman (spirit) will become one with Brahman (God) through the procession of death. 


\subsection{The term of Hambaruan, Panyalumpuk and Liau Haring Kaharingan}

The word Hambaruan is used to call spirit for a living human being whereas the word Panyalumpuk is used to call spirit for person who died but has not yet gone through death process as the last level of death and then the word Liau Haring Kaharingan is used to call human spirit that is going to go through the last level of death which is death process known as Tiwah.

Huang katika jete kea ie nukiii naharungking bahinge, mandehen riwute ije manjadi Aseng Panjang, tuntang palus atun pahalingei bitie umba kalawa ain Ranying Hatall Ai je rantep hinje umba ie; jete inyewut Hambaruan.

Translation:

In that moment He uttered; truthfully HE lives with HIM, HE is in form of shadow from the holy light of Ranying Hatalla which becomes one with Him, and therefore that is in form of life, called Hambaruan. (Panaturan, Chapter 20 verse 11 ).

In the book of Panaturan stated that all events happened from the power, mightiness, component of Mangku Amat Sangen body and Nyai Jaya Sangiang, become one to the wealth of nature in Pantai Danum Kalunen, and become the wealth for Raja Bunu decendents forever. Whereas Panyalumpuk (ātman) from Mangku Amat Sangen dan Nyai Jaya Sangiang, placed in Garing Nganderang Sukah Lumpung Matan Andau, located in the suburb of tasik kaharingan. Then Panyalumpuk, from the power of Ranying Hatalla, transform into "kambang garing", which then called and uttered with the word "ehem". The word "ehem" is always uttered when the holy verse of Tawur is pronounced (the holy verse of Tawur is always uttered to begin a ceremony or worship with an act of spreading rice/ behas tawur), the purpose is: as a symbol of power possessed by Ranying Hatalla in the name of "Panyalumpuk" Mangku Amat Sangen and Nyai Jaya Sangiang. After that Ranying Hatalla sees and arranges, whatever needs to be done with the name of Panyalumpuk "Spirit" they both open all power and make everything that comes from him, will become Kambang Garing, which is uttered and pronounced ehem. The word uttered Ehem is said in the beginning of reciting the holy verse of Tawur to exalt His power in the spirit of Panyalumpuk Mangku Amat Sangen and Nyai Jaya Nyangiang, as a reminder that everything was originated from Ranying Hatalla (Panaturan, chapter 40 verse 34- 35).

The manifestation of Ranying Hatalla in form of atman (Spirit), within human is called Hambaruan. Hambaruan is said to be the shadow of Ranying Hatalla holy light in every human (Panaturan, Chapter 20 verse 10-11). When human experience death, Hambaruan which is known as Liau Haring Kaharingan will return to Ranying Hatalla. Whereas the hard part of body (karahang tulang) and the soft part of body (balawang panjang) will return to its natural element of human resources such as soil, water, air and other natural resources is used by Angui Bungai Mama Lengai Tingang when resurrecting Kameluh Tanteluh Petak to the myth of Raja Bunu finding Nyalung Kaharingan Belum.

\subsection{Death Theology in Hindu Teaching}

According to PP (Government Regulation) number $18 / 1981$, someone is considered dead if his/her brain and brain stem are no longer functioning. However, 
death in religious ritual belief is when the ritual of the dead has been held. The book of Vraspati Tattwa mentions that death is a condition of separation between soul and the whole panca maha buta elements (five natural nature elements) that have formed body of all living creatures include human being, as follows:

Kala ikang mati ngarania wihturu mapasah lawan panca maha bhuta juga tekang atma ri sarira, ikang aganal juga ilang, ikang atma langeng tan molah, apan ibek ikang rat kabeh dening atma.

(Swastika I Ketut Pasek, 2008: 7)

Translation:

A death just means a separation of panca maha butha with atma inside the body; it is only the rough body disappears, while the atma still remains the same, because this world is full of atman (Swastika I Ketut Pasek, 2008:7)

The book of Mahabharata VI in Bhismaparwa (see penditi S. Nyoman, 2014), mentions that Arjuna saw the battlefield situation in Kurukshetra. He was full of fear of losing his siblings, masters and or beloved family members. He considered that killing his own family to seek world satisfaction or victory of the throne is a big sin and unforgivable. He believed that killing a teacher is a big sin. He was reluctant to fight his very loved and respected grandfather. Then, Krishna considered that Arjuna's thoughts and feelings are caused by his lack of wisdom on the meaning of war and death. In order to open and provide good understanding to Arjuna on the meaning of death and life, Krishna explained a teaching to Arjuna which is called samkhya-yoga. This teaching was then written into the book of
Bhagavadgita. Through a high level of teaching technique with spiritual sense, Krishna discussed and explained in detailed about the teaching of samkhya yoga to Arjuna. It starts from the teaching on how to overcome feelings and thoughts that are full of depression and sorrow, and how to stop tears when Arjuna speaks. The teaching process was started when Krishna denounced Arjuna first, and then he guided Arjuna to become a brave person. Krishna said as follows:

Where the soul weakening feelings come from in this difficult time? This feeling will not be recognized by the noble man, because it will not give a way to heaven and it only causes contempt, O Partha Putra Kunti.

Do not be defeated by traits that do not deserve to be embraced by a man, $\mathrm{O}$ Partha, as those traits are inappropriate to you. Throw away this small and fearful feelings and raise, $O$ Partha.

Even though Krishna said so, Arjuna felt that was still not able to fight against his siblings, grandfather Bhisma and his master, Drona. He was in confusion and sorrow to take actions, whether following Krishna's words or following his heart on the existence of his master, siblings and or his majestic grandfather Bhisma. He thought that it is better for him to live in this world by begging than killing his respected master. He thought that if he killed his siblings, grandfather and master, and he would enjoy his victory in this world from the killing, and then it is a big sin to him. In a doubtful and confused state of mind, and full of guilty feeling on what is called dharma, Arjuna asked Krishna to keep providing advises him to get him easier understanding on death and life. To the 
gloomy Arjuna in the middle of battlefield Kurukshetra, Krishna smiled and decreed about the differences between body and soul as follow:

You have been sad to those who do not deserve it, but you talk with full of wisdom words. Wise people are not sad to those who are dead and alive. There is never time where I am not there, and either do you, it is useless to have the kings, there will be another time after this we will perish from this life. As a soul in this body when we are still kids, young and old and so does it get into the other body, the calm soul is not influenced by this process situation. By the existence of indria connection from these objects, then occurs cold and warm, happy and sad situation. It appears and disappears and not eternal. Therefore, face it patiently, O Bharata (Arjuna)

A calm person, who is in the suffering and happiness, and cannot be disturbed by this situation, he is the only one who can get an eternal life, O Arjuna, the greatest man among human being. What do not exist will never exist, what exists will never do exist. People who have knowledge on truth know this state of situation. Be knowledgeable that what exists everywhere can be destroyed. The immortal creature will never be destroyed by anyone. The wadag body from the immortal soul can be destroyed and unlimited, known as the mortal wadag body. Therefore, go to the battle, O Bharata. It thinks that soul is the killer and it thinks that soul can be killed; both are not able to know the truth. The soul does not kill and cannot be killed. It never born and never dies anytime, it never appears and cannot disappear. The soul never knows birth, immortality, and it is always there. It cannot be killed if the body is killed.

Guns cannot cut jiwatma (soul), fire cannot burn it and water cannot wet it, and wind cannot dry it. It cannot be cut, it cannot be burned, and it cannot be dried. It is immortal, everywhere, does not change and does not move. It remains the same. It is said not in any form, unthinkable, unchangeable. Therefore, by knowing its nature, you should not be sad. We are not sad for something that is immortal. Even though if you think that jiwatma (soul) is a true soul, it always borns and always dies, however, O Arjuna, you should not be sad. Because when there is a birth, a death is certain, and it is also certain for birth to the death. Therefore, for two things that are inevitable, you should not be sad.

Be happy, the Kstrya (knights), O Partha (Arjuna) who get chance to fight, that appears without being searched, as it has no difference with the door to heaven. If you do not go to the truth war, then your obligation and honor will be broken and you will be sinful. If there is a war between truth and injustice, people must follow, even if they are being isolated as a result of fear and weakness of sin. Besides that, people will always talk about your badness, and for those who get honor, badness is worse than death. The big 
heroes will think that you have run from the war caused by fear and they who honor you in the past will not do the same thing. So do your enemies, they will question your bravery, and will say something inappropriate about you. What is worse than this? If you get killed in the battle field you will go to heaven, if you win you will enjoy this world, therefore, raise, O Arjuna, decide to go to the war.

By looking at the same for position and happiness, advantage and loss, victory and defeat, go to war. By doing so you will not be sinful.

Krishna explained that war does not kill the enemy's body, but to help the enemy stop doing sinful actions, then the truth can be enforced. Those who die in the battlefield do not die for nothing, but they have done their obligation or swadharma as an honor Kshtrya (knight). War may not be based on desire to kill, but it is just done to enforce justice and truth. For those Kshtrya who participate in war, their main obligation is to destroy untruth by destroying their enemies without thinking of the rewards for doing it. Then Krishna emphases that in the death process in the real world, it is only the rugged body dies, the soul does not although it is killed in many ways. After leaving the body, then the soul will look for a new body, like a person who takes off an old cloth and wear the new one. They are the past, now, and the future body, as individual spirits are everlasting forever and will experience reincarnation. Knowledge on spirit and body from various perspectives are described in the book of Bhagawadgita in Chapter II using the term of Samkhya-Yoga teaching.
Gita explained that Kshtrya who fights the enemies is indeed not killing anyone. They only run their obligation to defense the truth, their homeland, and joint rights; including building more honored new civilization. It is also mentioned that death at the battlefield for the Kshtrya is more honored than death at home, which is suffering from disease or dying because of natural disaster, accident and or in other forms. It is how the death is mentioned in Hindu teaching, death is not a scary condition, and instead it is just a separation between old body and the soul, which then soul will get new body for a more decent life.

\subsection{Death Mythology in Hindu Kaharingan Teaching.}

Death experienced by the entire human kind is mentioned in the book of Balian Tantulak Ambun Rutas, caused by 'panyalumpuk hambaruan'or the spirit of the dead body has been taken away by Karang Rajan Peres (king of disease-death causes), the Sipirit then brought by Karang Rajan Peres to the Laut Mangantung Sampang Hariran Manunyang (the death world), and kept inside Banama Bunter Dia Tawan Haluanan Ajung Bulat Isen Kamburia (coffin). Next, it is told that Raja Duhung Mama Tandang (the God of death) instructed Tarantung Garu (those who go to the world with him), to call Sanggiang Sahur (Human magical friend when they are still alive) to open the coffin, while Raja Duhung Mama Tandang (the God of death) go to take back panyalumpuk hambaruan.

Aku tulak bandu-bandung kayau nyembang karang rajan peres mambaleh handep bunu panjang habambulang tekap kamarau ambu. 
(Cited from the book of Balian Tantulak Ambun Runtas Matei)

Translation:

I go to meet Karang Rajan Peres to find out this person death cause.

Karang Rajan Peres handed over panyalumpuk liau haring kaharingan that reformed into Tanteluh Tingang Katen Antang. Finally, Raja Duhung Mama Tandang who opens the coffin, as Sangiang Sahur could not open it. Indeed, Raja Duhug Mama Tandang opened the coffin after asking for permission from Raja Entay Nyahu (God that is asked to take care of dead body during the burial ritual). The dead body then relived. Liu Haring Kaharingan then woke up to find out his siblings, and he felt hungry-thirsty, as he had been sleeping for a long time. Raja Duhung Mama Tandang then explained to the spirit of the death that he is no longer in the Pantai Danum Kalunen (in the world), instead he had died based on his promise to the Ranying Hatalla. However, the spirit of the death did not believe that he had died or no longer living in the world.

Raja Duhung Mama Tandang asked the spirit of the dead body to raise his right hand; however, he raised his left hand, and pointed to the down river when asked to the upriver. He still did not believe that he had died. Then, water was dropped to his head, Raja Duhung Mama Tandang gave him a mirror, and he saw there is Tunding Jarenang (a sign in form of white cloth that is usually used or tied up the dead people). Looking at this, he realized that he had died and separated from his siblings who are still alive forever, so that a big cry of him was inevitable. While crying, he expressed his sadness and said "how could Karang Rajan Peres has taken his life and separate him from his beloved family" $\mathrm{He}$ then begged to Raja Duhung Mama Tandang to return him to Pantai Danum Kalunen, as he still wanted to gather with his family. Raja Duhung Mama Tandang explained that based on his promise to Ranying Hatalla (God), that is the time comes then he will experience death as a way to return to Ranying Hatalla. However, please do not be disappointed or broken hearted, as I will take you to Lewu Bukit Nalian Lanting Rundung Kereng Naliwu Rahan or Lewu Tatau Habaras Bulau Babusung Hintan Karangan Lamiang together with Balu Indu Rangkang Penyang, Mina Sulen Perang Matan Andau.

Next, Raja Duhung Mama Tandang gave a message to Sanguang Sahur to get back to his place which is Bukit Sandung Langit membawa Salumpuk Bulau Sambang Raung (the death coffin spirit) and Salumpuk Liau Balawang Panjang (body) to be delivered to Batang Danum Rutas Matei. On the way of Sangiang Sahur to meet Tinggi Tingang Mama Hanyi Bungai (the death world guard) and he gave Salumpuk Liau Balawang Panjang, before that Tinggi Tingang Mama Hanyi Bungai inducted Salumpuk Raung to be Balai Bulau Sali Rabia (gold house) or Balai Baputi Nahabengau Tanjung Sali Jaleang Nahapantung Salingkat as a temporal place for Salumpuk Liau Balawang Panjang while waiting for final level death ritual (tiwah) to Salumpuk Liau Balawang Panjang.

Sangiang Sahur also delivered the message of Raja Duhung Mama Tandang to Tinggi Tingang Mama Hanyi Bungai to spread a robe (rotan) across Batang Danum Runtas Matei and sticked a Patung Rutas and covered Balai Rutas with red fabric, which in Tiwah will be replaced with white fabric and the statue is unsticked again and the robe across the river is cut. After delivering the 
message, Sangiang Sahur directly returned to his place in Bukit Sandung Langit. Raja Duhung Mama Tandang had a task to take Liau Haring Kaharingan/Panyalumpuk Hambaruan (roh) to Bukit Nalian Lanting using Lasang Jambu Bahandang Gentui Lumpuk Muntei Bulau (wahana). Before leaving, Raja Duhung Mama Tandang instructed Liau Haring Kaharingan to take a bath in some places like when he was taken a bath in Nahunan (a name giving ritual when alive) ritual. The bathing ritual is done upside down. After the holy bath for the spirit/Liau Haring Kaharingan is done, then a final death level ritual called Tiwah/Wara/Ijambe/Nyorat is carried out to deliver the spirit to its original place, Ranying Hatalla.

\subsection{Death as a Way of "Freedom" for Eternity}

The Indonesian Great Dictionary provides a definition on the word "freedom" as a process, way, action to free something from an attachment, shackle and or problem. While John Stuart Mill, the first man who provides different definition on the differences between freedom to take actions and freedom by force. The, Isaiah Berlin provides explanations to what John Stuart Mill's (1993: 12) said through two perspectives as positive and negative freedoms, as mentioned in the following quote:

John Stuart Mill, in his work, On Liberty, was the first to recognize the difference between liberty as the freedom to act and liberty as the absence of coercion. In his book, Two Concepts of Liberty, Isaiah Berlin formally framed the differences between these two perspectives as the distinction between two opposite concepts of liberty: positive liberty and negative liberty. The latter designates a negative condition in which an individual is protected from tyranny and the arbitrary exercise of authority, while the former refers to having the means or opportunity, rather than the lack of restraint, to do things.

Both concepts on freedom that is intended by Isaiah Berlin is that negative freedom is a circumstance where an individual is well-maintained or be spared from tyranny and dominion freely without being limited by the another party. While the positive freedom is strongly related to civil rights that are naturally have been equipped in each individual. John Stuart Mill provides a quite sharp view on "soft tyranny" (hidden) and collective freedom by explaining the harm principle concept. Understanding on this concept is very important when someone talks about freedom, as all of this becomes one idea on freedom as a philosophy. From philosophy point of view, moral has to overcome tyranny in all forms of move that relates to other parties, not vice versa. If not, the people will form a downgrade system community-based, and not putting collective interests, not in order or well maintained and full of failure and tyranny (John Stuart Mill, 1993: 12-16).

The Hindu teaching believes that freedom is not in the physical meaning only, but also mentally, which is 'freedom in life is free from attachment to the world, free from karma law, free from reincarnation or Moksa. In more details, freedom is explained in some Hindu Philosophy such as in the philosophy of Advaita Vedānta, Visiștāadvaita Vedānta, and Sāmkhya. Advaita Vedānta philosophy defines Moksa is a matter of direct realization 
of something which is existent from eternity thought it is hidden from our view. When the limitations are removed, the soul is liberated. It remains where it is, what it is and eternally was, and the first principle of all things. It is the peace that the world can never give, nor take away, the supreme and only blessedness. That which is real in the absolute sense, immutable, eternal, all-penetrating like akasa, exempt from all change, all-satisfying, undivided, whose nature is to be its own light, in which neither good or evil, nor effect, nor past nor present nor future has any place, this incorporeal is called liberation.

idai் tu pāramārthikaim, ùtastham, nityam, vyomavat sarvavyāpi, sarvavikriyārahitam, nityatrptam

svayam jyotis svabhāvam, yatra dharmādharmau sahakāryena kālatrayam ca nopāvartate tad aśarīram mokṣākhyam.

Translation:

Moksa is a matter of direct realization of something which is existent from eternity thought it is hidden from our view. When the limitations are removed, the soul is liberated. It remains where it is, what it is and eternally was, and the first principle of all things. It is the peace that the world can never give, nor take away, the supreme and only blessedness. That which is real in the absolute sense, immutable, eternal, all-penetrating like akasa, exempt from all change, all-satisfying, undivided, whose nature is to be its own light, in which neither good or evil, nor effect, nor past nor present nor future has any place, this incorporeal is called liberation. (Radhakrishnan, 2008: 593-594).

Sāmkhya philosophy affirms that freedom or mokșa is a condition of prakrti (world material element) which is released or free from purusa (consciousness). Freedom can be achieved or got by anyone or any living creatures, anytime and the freedom is not only achieved after experiencing death, but also when alive, which is called jiwanmukti, temporal soul emancipation when we still live in our body. Mokșa that is achieved after death is called videhamukti or soul emancipation of all physical and soft body. This videmukti condition is called moksa as absolute freedom or the highest one - perfection.

It is possible for every self to realize itself in this way and thereby attain liberation in life in this world. This kind of liberation is known as jivvanmukti or emancipation of soul while living in this body. After the death of its body, the liberated self attains what is called videhamukti or emancipation of spirit from all bodies, gross and subtle. This ensures absolute and complete freedom (Satischandra Chatterjee dan Dhirendramohan Datta, 2008: 283).

Meanwhile, the Visiștāadvaita Vedānta philosophy initiated by Rāmānuja, explains the definition of moksa as the passed tyranny from the worldly life difficulties toward heaven and or Vaikuntha Loka, where he will exist forever in personal happiness with God, but never be identical with God. The final freedom can only be achieved by bhakti. God grace come through obedience (prapatti) or absolute self-surrender (His aim is to proclaim the doctrine of salvation (mokșa) 
through bhakti or devotion ...). The self freedom through bhakti develops through two concepts, markata nyaya or monkey theory, is a bhakta has to be like a monkey child who has to help its self to be dependent to its mother (personal spirit-Narayana), and the second is marjara nyaya or theory of kitten, is a total surrender when its mother brings it without efforts to its self. That is meant by mokṣa in the Visișțādvaita Vedānta philosophy (Theos Bernard, 1981: 10).

In the book of Panaturan chapter 29 verse 4, it mentions that Ranying Hatalla has told Raja Bunu as human ancestor that Raja Bunu generation who live in Pantai Danum Kalunen (world), when the time comes will return to Ranying Hatalla through a death process.

Hete Ranying Hatalla bapander panjang umba Raja Bunu, tuh bitim palus panarantang aim, akan ilaluhan kareh manyuang Batang Petak ije jadi injapaKu hayak inyewutku jete Pantai Danum Kalunen tuntang panarantang aim te dapit jeha puna bagin matei.

Translation:

Ranying Hattala said to Raja Bunu, that Raja Bunu and his generation who are inheritted from Ranying Hatalla to dominate the world, which is called life, and Raja Bunu generation has been determined to retun to Ranying Hatalla trhough a death.

The book of Panaturan chapter 32 verse 4, mentiones that human life or Raja Bunu generations who live in Batang Danum Injam Tingang/ Pantai Danum Kalunen do only live for temporary, it is like leaving a home area to make a new living, and in the end will return to where they come from, Ranying Hatalla. It is mentioned wisely and honorly about the death condition in the book of Panaturan, however, death for most of people especially Hindu Kaharingan is a scary disaster and not wanted by anyone. The book of Panaturan clearly mentions that death is a way for human to return to Ranying Hatalla itself, as said by Ranying Hatalla in chapter 29 verse 4 in the book of Panaturan above. Life in this world is only for temporary, as a nomad, when the time journey has finished, then we will return. Return to whom and where? Return to Ranying Hatalla in Lewu Tatau Dia Rumpung Tulang Nasi Numpui Burung (eternity world with Ranying Hatalla).

The question is why living in this world is called as moving from a home area to make a new life in Batang Danum Tingang? It is like a journey that we do in this real world. It is done to improve our valence-dignity, whether in a journey to improve knowledge, welfare, and or mental quality. All forms of journey above in the end are aimed at a point, to improve valence and dignity as human who deserves to live. The journey as mandated by Ranying Hattala to human being who are placed in Batang Danum Injam Tingang Nasi Nampui (world). Human is created in this world for a mission "harvesting and settlement" for undone past actions that we haven't finished to accept or feel when we did them. Human is a living creature with more strength compared to other creatures. We are given opportunities by Ranying Hatalla to make improvements and feel the impacts of our past actions or in the previous life. In the end, when human returns to Ranying Hatalla, they are already decent, white-clean, and holy without spots or sins.

The condition in which human has to return to Ranying Hatalla in holiness, cleanliness from sins, can be understood through symbolic meaning that it seen in the 
Mahadewa soap opera in one of private TV station in Indonesia. The story is about Sati who is the life spouse of Dewa Siwa, but it is very difficult for her to marry and live with Dewa Siwa. This is because Sati feels that she does not have the "appropriateness" to be Dewa Siwa's wife. This is because Sati is an ordinary human, whereas Siwa is a God. How an ordinary human could marry to a God. It also applies to us. How could we deserve to be united again with Ranying Hatalla if we are still dirty, sinful, and full of debts of our past actions? Therefore, as we are presence back in the world, we have chance to improve ourselves, quality and quantity of life, mental, and physics, so that when our journey is complete, we are ready to return to Ranying Hatalla in the white-clean and decent condition. This is affirmed in the book of Panaturan chapter 63 verse 14. That human comes from Ranying Hatalla in the "perfumed" holy and clean) condition, then when returning back to Ranying Hatalla we must be in "perfumed" condition.

Kalute ampin Ranying Hatalla Langit jadi manjadian hayak ma-atuh kakare taluh handiai akan pambelum panakan Raja Bunu ije belum huang Pantai Danum Kalunen, uka sewut sarita bahalap, kalute kea amun ewen buli Ranying Hatalla tutu-tutu barasih kilau tamparae ie dumah bara Ranying Hatalla.

Translation:

As Ranying Hatalla has created his will to manage everything for human life generation of Raja Bunu who lives in the world to make his name be glorified. The same thing happens when he returns to Ranying Hatalla Langit, he must be completely clean as he comes and created by Ranying Hatalla.
The book of Sarasammucaya (sloka 46) mentions: be grateful that we are created in this word in human form, as only human that can help themselves, through good actions". Honored opportunity owned by human to improve them has been implicitly symbolic in the book of Panaturan through a mythology of shape change Manyamei Malinggar Langit and Kameluh Bajaramut Hintan that can achieve the eternity or return back to Ranying Hatalla after experiencing some shapes changes in different times. Starting from their shape as Manyamei Malinggar LangitKameluh Bajarumut Hintan, transformed into Manyamei Tunggul Garing-Kameluh Putak Bulau, and then transformed again into Mangku Amat Sangen-Nyai Jayang Sangiang. The shape transformation happens as a result of their actions when they became Manyamei Malinggar Langit-Kameluh Bajarumut Hintan, which truly their presence at that time was desired by Ranying Hatlla as two figures who can act like Ranying Hatalla in order to maintain the living creatures created by Ranying Hatalla. They both did a big sin, and then both are seen not worthy to be Ranying Hatalla desired figures. Next, when they were in the form of Mangku Amat Sangen and Nyai Jayang Sanging, then they got the perfection through a death and returned to Ranying Hatalla. The same applies to human, they will keep evolving in different shapes from time to time, and in the end they will deserve to be human who meet requirements to return to Ranying Hattala.

Next, in the book of Panaturan chapter 32 verses 6 , it mentions that when human dies, then the other alive human obligation is to do other procession or death ritual to those who are dead. As it is impossible to have the dead people to do the death ritual to themselves. Therefore, Ranying Hatalla has 
decreed to the generation of Raja Bunu, which is human, as written in the book of Panaturan, that human bodies is united with their spirit when they are alive, then when they die, human is divided into three parts, which are: soft body, rough body and spirit. When die, the soft body is called Liau Karahang Tulang, the rough body is called Balawang Panjang and the spirit is called Liau Haring Kaharingan. The three components of Liau have their own ritual which is called Tiwah in Dayak Ngaju tradition and called Wara in Dayak Dusun tradition. After the Tiwah, then the three components of the dead person are believed can be united again, Balawang Panjang and Karahang Tulang returns to the natural elements that is symbolized as a figure of Jatha Balawang Bulau Kanaruhan Bapager Hintan (material elements), while the human Spirit returns to Ranying Hatalla (Panaturan chapter 60 verse 6-7).

\section{Conclusion}

The thoughts of death always appear in each human mind and heart from time to time. Human is afraid of death as they do not know what happens after death. Human wants to live longer and longer, because death is understood will stop human permanently to enjoy the worldly pleasure, in the form of sorrow and happiness. Human does not want to leave the worldly pleasure. Therefore, death is something that is unwanted by each human. Indeed, the book of Hindu Literature mentions that death is not something we need to be scared of, as death is a way for the Soul to get its freedom from human physical body attachment. Death is mentioned in the book of Bhagavadgita as a process of body turnover for the Soul like cloth changing for each human body every time we want to have new cloth that is cleaner and healthier for our body. It is the human condition when experiencing death. The book of Brahadaranyaka Upanisad also said the same thing. Whereas, Hindu Kaharingan teaching that is written in the book of Panaturan mentions that death is a way to return to Ranying Hatalla. Because human life in this world is just for temporary like a nomad, in which sometime will return to a place where he came from. The book of Panaturan mentions that the purpose of human presence in the world is to clean themselves from various thoughts, words and sinful actions, as it is only with holy and clean actions, words, and thoughs human can return to Ranying Hatalla. "kalute kea amun ewen buli Ranying Hatalla tutu-tutu barasih kilau tamparae ie dumah bara Ranying Hatalla" (the same happens when they return to Ranying Hatalla, they must be holy and clean as when they are created by Ranying Hattala). Therefore, the meaning of death in the book of Panaturan is as a way of Liau Haring Kaharingan (spirit) freedom from the cover of Karahang Tulang and Balawang Panjang to be reunited with Ranying Hatalla in the eternal world forever. The eternal world is no sorrow, sadness and happiness.

\section{References}

Dapartemen Pendidikan Nasional. 2008. Kamus Besar Bahasa Indonesia (Edisi Keempat). Penerbit Balai Pustaka. Jakarta

Henricus Darmada. 2000. Cahaya dalam Kegelapan. Penerbit PT Gramedia Pustaka Utama Jakarta.

John Stuart Mill. 1993. On Liberty and Utilitarianism. New York: Bantam Books. New York

Juan Masearo \& Swami Harshananda (editor Ngakan Putu Putra). 2010. Upanisad 
Himalaya Jiwa. Penerbit Media Hindu Jakarta.

Kiriana, I. N. (2017). Ngaben Conception In Lontar Siwa Tattwa Purana. Vidyottama Sanatana: International Journal of Hindu Science and Religious Studies, 1(2), 84-92.

Komaruddin Hidayat. 2008. Psikologi Kematian: Merubah Ketakutan Menjadi Optimis. Penerbit Hikmah (PT. Mizan Publika). Jakarta Selatan

MB-AHK Pusat Palangka Raya. 2009. Panaturan. Penerbit Widya Dharma Denpasar.

Muhammad Damm. 2011. Sebuah Risalah tentang Eksistensi dan Ketiadaan. Penerbit Kepik Depok.

Pudja Gde. 2005. Bhagavadgita (Pancama Veda). Penerbit Paramitha Surabaya.

Sudarsana, I. K. (2017). Interpretation Meaning of Ngaben for Krama Dadia Arya Kubontubuh Tirtha Sari Ulakan Village Karangasem District (Hindu Religious Education Perspective). Vidyottama Sanatana: International Journal of Hindu Science and Religious Studies, 1(1), 1-13.

S. Radhakrishnan. 2006. The Pricipal Upanisads. Harper Collins Publishers India New Delhi.

S. Radhakrishnan. 2008.Indian Philosophy Vol. II. Oxford India Paperbacks. New Delhi

Satischandra Chatterjee \& Dhirendramohan Datta. 2008. An Introduction to Indian Philosophy. University of Calcutta

Swastika Pasek I Ketut. 2008. Ngaben. Penerbit CV. Kayumas Agung Denpasar.

S.Pendit Nyoman. 2014. Mahabharata. PT. Gramedia Pustaka Utama. Jakarta.
Theos Bernard. 1981. Hindu Philosophy. Motilal Banarsidas Jawahar NagarNew Delhi

Tiwi Etika. 2017. Penuturan Simbolik Konsep Panca Sraddha Dalam Kitab Panaturan. Diterbitkan STAHN-TP Palangka Raya bekerjasama dengan An1mage Bumi Jati Tangerang-Banten 